\title{
Correction to: Flexible Ubers and Fixed Taxis: the Effect of Fuel Prices on Car Services
}

\section{Thomas J. Weinandy ${ }^{1}$ Michael J. Ryan ${ }^{1}$}

Published online: 11 March 2021

(c) Springer Science+Business Media, LLC, part of Springer Nature 2021

\section{Correction to: Journal of Industry, Competition and Trade https://doi.org/10.1007/s10842-020-00351-3}

Correction is needed to the original publication. Equation 15 in the Appendix section is listed as a markup code.

The original article has been corrected.

Publisher's Note Springer Nature remains neutral with regard to jurisdictional claims in published maps and institutional affiliations.

The online version of the original article can be found at https://doi.org/10.1007/s10842-020-00351-3

Thomas J. Weinandy

thomas.j.weinandy@wmich.edu

1 Department of Economics, Western Michigan University, 1903 W Michigan Ave, Kalamazoo, MI 49008, USA 